Virginia Commonwealth University

VCU Scholars Compass

1996

\title{
Termolecular proton transfer reactions assisted by ionic hydrogen bond formation: Reactions of aromatic cations with polar molecules
}

George M. Daly

Virginia Commonwealth University

Michael Mautner

Virginia Commonwealth University, mmautner@vcu.edu

Y. B. Pithawalla

Virginia Commonwealth University

M. Samy El-Shall

Virginia Commonwealth University, mselshal@vcu.edu

Follow this and additional works at: http://scholarscompass.vcu.edu/chem_pubs

Part of the Chemistry Commons

Daly, G. M., Meot-Ner, M., \& Pithawalla, Y. B., et al. Termolecular proton transfer reactions assisted by ionic hydrogen bond formation: Reactions of aromatic cations with polar molecules. The Journal of Chemical Physics, 104, 7965 (1996). Copyright (C) 1996 American Institute of Physics.

\section{Downloaded from}

http://scholarscompass.vcu.edu/chem_pubs/44

This Article is brought to you for free and open access by the Dept. of Chemistry at VCU Scholars Compass. It has been accepted for inclusion in Chemistry Publications by an authorized administrator of VCU Scholars Compass. For more information, please contact libcompass@vcu.edu. 


\title{
Termolecular proton transfer reactions assisted by ionic hydrogen bond formation: Reactions of aromatic cations with polar molecules
}

\author{
G. M. Daly, M. Meot-Ner, Y. B. Pithawalla, and M. S. El-Shall ${ }^{\mathrm{a})}$ \\ Department of Chemistry, Virginia Commonwealth University, Richmond, Virginia 23284-2006
}

(Received 15 May 1995; accepted 9 February 1996)

\begin{abstract}
We present a new method that applies resonant-two-photon ionization to generate reactant ions selectively in the source of a high-pressure mass spectrometer (R2PI-HPMS) for kinetic and equilibrium studies. Applications to reactions that would be obscured otherwise in a complex system are illustrated in mixtures of benzene with polar solvent molecules (S). We observe a novel type of proton transfer reactions from $\mathrm{C}_{6} \mathrm{H}_{6}{ }^{+\bullet}$ to two $\mathrm{S}$ molecules where $\mathrm{S}=\mathrm{CH}_{3} \mathrm{CN}, \mathrm{CH}_{3} \mathrm{OH}$, $\mathrm{C}_{2} \mathrm{H}_{5} \mathrm{OH}$ and $\mathrm{CH}_{3} \mathrm{COOC}_{2} \mathrm{H}_{5}$, and from $\mathrm{C}_{6} \mathrm{H}_{5} \mathrm{CH}_{3}{ }^{+}$to two $\mathrm{S}$ molecules where $\mathrm{S}=\mathrm{CH}_{3} \mathrm{OH}$ and $\mathrm{C}_{2} \mathrm{H}_{5} \mathrm{OH}$ to form protonated solvent $\mathrm{S}_{2} \mathrm{H}^{+}$dimers. The reactions are driven by the strong hydrogen bonds in the $\mathrm{S}_{2} \mathrm{H}^{+}$dimers and therefore require the formation of the hydrogen bond concertedly with proton transfer, to make the process energetically feasible. The adducts $\left(\mathrm{C}_{6} \mathrm{H}_{6}{ }^{+\bullet}\right) \mathrm{S}$ are observed with blocked solvent molecules where the subsequent switching reaction to yield $\mathrm{S}_{2} \mathrm{H}^{+}$is slow, but not with alcohol reactants that can form hydrogen-bonded chains that facilitate fast subsequent proton extraction. Correspondingly, kinetic simulations suggest that the mechanism proceeds through $\left(\mathrm{C}_{6} \mathrm{H}_{6}{ }^{+\bullet}\right) \mathrm{S}+\mathrm{S} \rightarrow \mathrm{S}_{2} \mathrm{H}^{+}+\mathrm{C}_{6} \mathrm{H}_{5}{ }^{\bullet}$ and $\mathrm{C}_{6} \mathrm{H}_{6}{ }^{+\bullet}+2 \mathrm{~S} \rightarrow \mathrm{S}_{2} \mathrm{H}^{+}+\mathrm{C}_{6} \mathrm{H}_{5}{ }^{\bullet}$ reactions, respectively. The rate coefficients of these reactions are in the range $10^{-13}-10^{-12} \mathrm{~cm}^{3} \mathrm{~s}^{-1}$ for the reaction through a bimolecular switching channel and in the range $10^{-26}-10^{-28} \mathrm{~cm}^{6} \mathrm{~s}^{-1}$ for reaction through a direct termolecular proton extraction mechanism. The relation to energetics and reactant structure is examined. (c) 1996 American Institute of Physics. [S0021-9606(96)02918-8]
\end{abstract}

\section{INTRODUCTION}

The interactions between aromatic cations and polar molecules are of fundamental interest in many areas of chemistry and biology. A detailed understanding of these interactions is necessary for the development of proper theories for many important phenomena such as ion solvation, ${ }^{1-3}$ proton transfer in organic reactions ${ }^{4,5}$ and in biological systems, ${ }^{6-8}$ ion-induced nucleation, ${ }^{9-11}$ cationic polymerization and other condensed phase processes that involve aromatic cations. ${ }^{12,13}$ For example, extraction of protons from radical cations by solvent molecules may have important implications in radiation and polymerization processes since such reactions may terminate polymerization chains and may explain the detrimental effects observed for water in cationic polymerization. ${ }^{13}$

Although the thermochemistry and kinetics of many ionmolecule reactions have been determined by pulsed high pressure mass spectrometry (PHPMS) ${ }^{14-16}$ measurements of the reactions of aromatic cations with polar molecules remain elusive due to unfavorable kinetics and ion stability. Ionization by electron impact or chemical ionization tends to be nonselective, and also deposits large amounts of excess energy in the ion. In binary or ternary mixtures, direct ionization of a single component can lead to exothermic proton transfer reactions followed by fast stepwise ion solvation that dominates the observed chemistry and obscures the reactions of minor constituents. Ion injection methods largely overcome this limitation and are employed in several laboratories. ${ }^{17-20}$ Here we present an alternative and simpler

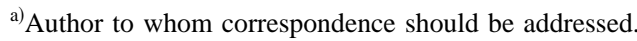

method, by the coupling of resonant-two-photon-ionization (R2PI) to an HPMS system in order to selectively generate low energy aromatic ions within a gaseous mixture that also contains an excess of a polar solvent.

R2PI is a highly sensitive spectroscopic and ionization technique that measures the photoabsorption cross-section of a specific chromophore using the strong enhancement of the two photon ionization probability produced by tuning into resonance at the one photon energy. ${ }^{21,22}$ This is also one of the most rigorously fragmentation-free methods of preparing molecular ions. ${ }^{23}$ This is particularly important for thermochemistry measurements since isomerization of the molecular ions may take place if the ions are generated with higher energy content.

The systems of interest for the present study consist of an aromatic radical cation, $\mathrm{X}^{+}(\mathrm{X}=$ benzene or toluene $)$ interacting with protic or aprotic solvent molecules, $\mathrm{S}$ $\left(\mathrm{S}=\mathrm{H}_{2} \mathrm{O}, \mathrm{CH}_{3} \mathrm{OH}, \mathrm{C}_{2} \mathrm{H}_{5} \mathrm{OH}, \mathrm{CH}_{3} \mathrm{CN}, \mathrm{CH}_{3} \mathrm{COOC}_{2} \mathrm{H}_{5}\right.$ ) under high pressure conditions (1-5 Torr). The application of R2PI coupled with HPMS for the study of such systems allows the examination of proton transfer reactions of the type:

$$
\mathrm{X}^{+\bullet}+n \mathrm{~S} \rightarrow \mathrm{X}^{+\bullet} \mathrm{S}_{n} \rightarrow \mathrm{S}_{n} \mathrm{H}^{+}+(\mathrm{X}-\mathrm{H})^{\bullet} .
$$

In reaction (1) the proton affinity of each of the chosen solvent molecules, $\mathrm{S}$, is insufficient to facilitate proton transfer, but the presence of two or more solvent molecules can result in proton transfer concerted with the formation of a proton bound dimer $\mathrm{S}_{2} \mathrm{H}^{+}$, which makes the overall process exothermic. These reactions are similar to those observed by Sieck and Searles in a non-resonant continuous photoionization HPMS. ${ }^{24}$ They studied the reactions of alkane molecular cations with water and found that the parent ions from cy- 
clohexane, cyclopentane, $i$-butane, $n$-butane, $i$-pentane, $n$-pentane and $n$-hexane react exclusively via a termolecular mechanism involving two water molecules to produce a protonated water dimer. Analogous reactions have also been observed following the R2PI of binary neutral clusters such as toluene. $\mathrm{S}_{n}$ where $\mathrm{S}=\mathrm{H}_{2} \mathrm{O}, \mathrm{CH}_{3} \mathrm{OH}, \mathrm{CH}_{3} \mathrm{OCH}_{3}$ and $\mathrm{NH}_{3} .{ }^{25,26}$ These intracluster proton transfer reactions show unique size effects which arise from the relative proton affinities of the benzyl radical and the solvent subcluster $\left(\mathrm{S}_{n}\right)$. The comparison between the gas phase and cluster reactions should provide valuable insights regarding the relative efficiencies of collisional stabilization of intermediates via collisions in the gas phase or evaporative cooling from the clusters.

Of particular interest in the present study is the effect of the structure of the protonated dimer on the overall rate of the reaction. The solvent molecules considered here represent two types of interaction. In the first group $\left(\mathrm{H}_{2} \mathrm{O}, \mathrm{CH}_{3} \mathrm{OH}\right.$ and $\mathrm{C}_{2} \mathrm{H}_{5} \mathrm{OH}$ ), extended $\mathrm{H}$-bonded chains or networks can be formed past the generation of the $\mathrm{S}_{2} \mathrm{H}^{+}$dimer while for $\mathrm{CH}_{3} \mathrm{CN}$ and $\mathrm{CH}_{3} \mathrm{COOC}_{2} \mathrm{H}_{5}$, the protonated dimers are blocked and the addition of the third molecule may not be favorable. Also, the systems considered here cover a wide range of exothermicity and allow one to investigate the effect of increasing exothermicity on the overall rates of these reactions.

\section{EXPERIMENT}

The HPMS source consists of a $4 \times 4 \mathrm{~cm}^{2}$ aluminum block mounted on a copper base wrapped in coolant coils for temperature control. ${ }^{27}$ The source is fitted with quartz windows through which the laser beam enters and exits. The reactant and product ions escape through a precision pinhole (200 $\mu \mathrm{m}$, Melles Griot) and are analyzed with a quadrupole mass filter. Cell temperature is monitored through two type T copper-constantan thermocouples (Omega). Gas mixtures are prepared in a heated $\left(>100{ }^{\circ} \mathrm{C}\right) 2 \mathrm{~L}$ flask and admitted to the ion source at selected pressures via an adjustable needle valve. Cell pressure is monitored with a capacitance manometer (MKS, 1301) coupled with the gas inlet tube. Measurements are typically made over source pressures of $0.1-5$ Torr. The concentration of analytes range from $0.005-10 \%$ in a suitable bath gas $\left[\mathrm{N}_{2}\right.$ or Ar, ultra pure (Airco) $]$. Mixtures are typically made by $\mu \mathrm{L}$ injection of liquid samples into an evacuated heated sample flask followed by the addition of the bath gas.

The laser beam is slightly focused within the center of the cell with a quartz spherical lens $(f=60 \mathrm{~cm}, d=2.54 \mathrm{~cm})$. The laser output $(\lambda \approx 259 \mathrm{~nm}, 100-500 \mu \mathrm{J}, \Delta \tau=10 \mathrm{nsec}, 20$ $\mathrm{Hz}$ repetition rate) is generated by a $\mathrm{XeCl}$ excimer pumped dye laser (Lambda Physik LPX 101 and FL-3002, respectively). Coumarin 503 (Exciton) dye laser output passes through a $\beta-\mathrm{BaB}_{2} \mathrm{O}_{4}$ crystal (CSK) cut at $52^{\circ}$ to generate a tunable frequency-doubled output of $10^{-8} \mathrm{~s}$ pulses. The spatially filtered (using a set of four quartz Pellin-Broca prisms) ultraviolet radiation passes through the high pressure cell and the focusing is adjusted to minimize three photon processes (i.e., unimolecular fragmentation) while still providing suffi-

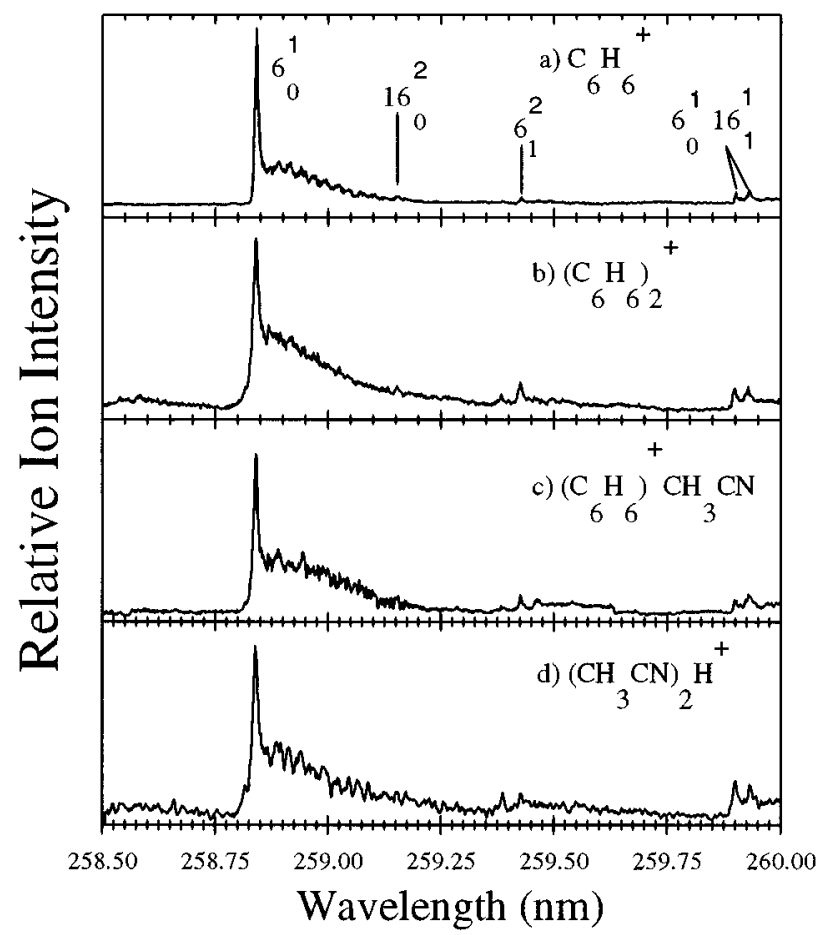

FIG. 1. Wavelength dependence for ions in R2PI-HPMS with various mixture compositions at $298 \mathrm{~K}$. (a) Benzene ion, $\mathrm{C}_{6} \mathrm{H}_{6}^{+}$, (b) benzene dimer ion, $\left(\mathrm{C}_{6} \mathrm{H}_{6}\right)_{2}^{+\cdot}$, (c) benzene/acetonitrile cluster ion, $\mathrm{C}_{6} \mathrm{H}_{6}^{+} \cdot \mathrm{CH}_{3} \mathrm{CN}$, and (d) protonated acetonitrile dimer, $\left(\mathrm{CH}_{3} \mathrm{CN}\right)_{2} \mathrm{H}^{+}$.

cient ion current (photon power density $\approx 10^{5} \mathrm{~W} / \mathrm{cm}^{2}$ ).

The quadrupole mass filter (Extrel C-50, equipped with $3 / 8$ in. diameter rods and has a resolution better than $1 \mathrm{amu}$, FWHM, within the mass range 1-500 amu) is mounted coaxially to the ion exit hole. The ion current from the electron multiplier is amplified and recorded with a $350 \mathrm{MHz}$ digital oscilloscope (LeCroy 9450).

Three types of basic measurements can be made with the current setup; (1) Ion temporal profiles following the laser ionization pulse may be averaged over several laser pulses (500-1000). This is used for the kinetic measurements and for obtaining the normalized ion intensity for the equilibrium thermochemistry measurements. (2) A mass scan can be performed at a fixed wavelength which is typically used to identify all the ions generated following the laser pulse. (3) A laser wavelength scan can be obtained by monitoring a specific ion (fixed $\mathrm{m} / \mathrm{z}$ ). This provides the electronic absorption spectrum of the selected chromophore and establishes the identity of the primary ions generated by R2PI.

\section{RESULTS AND DISCUSSION}

\section{A. Photoabsorption spectrum of benzene in HPMS}

Figure 1 shows the dependence of the benzene ion signal on wavelength in the vicinity of the benzene $6_{0}^{1}, S_{1} \leftarrow S_{0}$ transition $(\sim 259 \mathrm{~nm})$. The data are recorded by scanning the laser wavelength while monitoring the $\mathrm{C}_{6} \mathrm{H}_{6}{ }^{+} \cdot$ ion signal intensity $(m / z, 78, \Delta m \leqslant 1$ amu). Each wavelength-intensity data point is obtained by averaging at least 50 laser pulses. 
TABLE I. Thermodynamic quantities ${ }^{\mathrm{a}}$ for the formation of cationic clusters.

\begin{tabular}{llc}
\hline \hline \multicolumn{1}{c}{ Cluster } & $\Delta G^{\circ} 298\left(\mathrm{kcal} \mathrm{mol}^{-1}\right)$ & $\Delta H^{\circ}\left(\mathrm{kcal} \mathrm{mol}^{-1}\right)$ \\
\hline$\left(\mathrm{C}_{6} \mathrm{H}_{6}\right)_{2}^{+\bullet}$ & $-9.6 \pm 0.2$ & -17.8 \\
$\left(\mathrm{C}_{6} \mathrm{H}_{6}^{+*}\right)\left(\mathrm{CH}_{3} \mathrm{CN}\right)$ & $-7.1 \pm 0.2$ & -13.7 \\
$\left(\mathrm{C}_{6} \mathrm{H}_{6}^{+\cdot}\right)\left(\mathrm{CH}_{3} \mathrm{CN}\right)_{2}$ & $-4.8 \pm 0.2$ & -11.4 \\
$\left(\mathrm{C}_{6} \mathrm{H}_{6}^{+*}\right)\left(\mathrm{CH}_{3} \mathrm{COOC}_{2} \mathrm{H}_{5}\right)$ & -6.0 & -12.6 \\
$\left(\mathrm{C}_{6} \mathrm{H}_{5} \mathrm{CH}_{3}^{+\bullet}\right)\left(\mathrm{C}_{6} \mathrm{H}_{6} \mathrm{CH}_{3}\right)$ & $-7.5 \pm 0.2$ & -16.1 \\
$\left(\mathrm{C}_{6} \mathrm{H}_{5} \mathrm{CH}_{3}^{+\bullet}\right)\left(\mathrm{CH}_{3} \mathrm{CN}\right)$ & $-6.3 \pm 0.2$ & -12.9 \\
\hline \hline
\end{tabular}

${ }^{\mathrm{a}} \Delta S^{\circ}$ values for (benzene) ${ }_{2}^{+}$and (toluene) ${ }_{2}^{+}$are estimated as $-27.5 \mathrm{cal} \mathrm{mol}^{-1}$ $\mathrm{K}^{-1}$ and $-29.0 \mathrm{cal} \mathrm{mol}^{-1} \mathrm{~K}^{-1}$ from similar literature reactions. ${ }^{32}$ For other clusters, $\Delta S^{\circ}$ values of $-22.0 \mathrm{cal} \mathrm{mol}^{-1} \mathrm{~K}^{-1}$ are estimated from similar reactions. ${ }^{34} \Delta H^{\circ}$ values are calculated from $\Delta G^{\circ}+T \Delta S^{\circ}$.

The spectral envelope for the $6{ }_{0}^{1}$ band reflects the thermal population of the ground state $\left(\nu^{\prime \prime}=0\right)$ rotational levels in neutral benzene at $298 \mathrm{~K}$. The estimated density of rotational states is 600 lines $/ \mathrm{cm}^{-1}$ which is impossible to resolve given a laser bandwidth of $0.4 \mathrm{~cm}^{-1}{ }^{28}$ Vibrational "hot" bands are also observed and the overall spectrum is in excellent agreement with the published gas phase absorption spectrum. $^{29,30}$

Similar to the $\mathrm{C}_{6} \mathrm{H}_{6}{ }^{+\bullet}$, we also obtained the wavelength dependence of the dimer cation $\left(\mathrm{C}_{6} \mathrm{H}_{6}\right)_{2}{ }^{+\bullet}$ (Fig. 1b), the $\mathrm{C}_{6} \mathrm{H}_{6}{ }^{+\bullet}\left(\mathrm{CH}_{3} \mathrm{CN}\right)$ adduct (Fig. 1c), and a reaction product ion $\left(\mathrm{CH}_{3} \mathrm{CN}\right)_{2} \mathrm{H}^{+}$(Fig. 1d) resulting from a proton transfer reaction that will be discussed in Sec. III B. The results clearly show that the three ions originate through the initial step of resonance ionization of the benzene molecule. Laser photoelectron measurements of benzene in a supersonic jet ionized by R2PI show that vibrational excitation may be present in the benzene ions following ionization. ${ }^{31}$ Following R2PI of benzene via the $6_{0}^{1}$ vibronic transition, the most populated vibrations are $\nu_{6}, \nu_{1}$ and $\nu_{16}$. In HPMS, thermalization of the ions by the bath gas will reduce the vibrational excitation. (At a source pressure of 1 Torr at $298 \mathrm{~K}$ the ions undergo $3 \times 10^{4}$ collisions with the carrier gas during $1 \mathrm{~ms}$ residence time.) However, as the spectra in Fig. 1 indicate, there is some population of these levels at $298 \mathrm{~K}$ in the neutral and it is likely that the vibrational excitation in the ion will be of a similar nature.

The time profiles of the $\mathrm{C}_{6} \mathrm{H}_{6}{ }^{+\bullet}$ and $\left(\mathrm{C}_{6} \mathrm{H}_{6}\right)_{2}{ }^{+\bullet}$ ion signals following the laser pulse show a constant $\left(\mathrm{C}_{6} \mathrm{H}_{6}\right)_{2}{ }^{+} / \mathrm{C}_{6} \mathrm{H}_{6}{ }^{+} \cdot$ ratio thus indicating the attainment of equilibrium. From the equilibrium ratio $\left(\mathrm{C}_{6} \mathrm{H}_{6}\right)_{2}{ }^{+} \cdot \mathrm{C}_{6} \mathrm{H}_{6}{ }^{+\bullet}$, we report a $\Delta G^{\circ}(298 \mathrm{~K})$ value of $-9.6 \pm 0.2 \mathrm{kcal} \mathrm{mol}^{-1}$ (Table I). With respect to the $\left(\mathrm{C}_{6} \mathrm{H}_{6}\right)_{2}{ }^{+\bullet}$ binding energy we note two literature values from PHPMS measurements, by Meot-Ner et al. $\quad\left(\Delta H^{\circ}=-17.6 \mathrm{kcal} \mathrm{mol}{ }^{-1}, \quad \Delta S^{\circ}=-27\right.$ cal $\left.\mathrm{mol}^{-1} \mathrm{~K}^{-1}\right),{ }^{32}$ and Hiraoka et al. $\left(\Delta H^{\circ}=-20.6\right.$ $\left.\mathrm{kcal} \mathrm{mol}{ }^{-1}, \Delta S^{\circ}=-28 \mathrm{cal} \mathrm{mol}^{-1} \mathrm{~K}^{-1}\right),{ }^{33}$ with a difference somewhat larger than the combined error limits. Using the average $\Delta S^{\circ}$ value of $-27.5 \mathrm{cal} \mathrm{mol}^{-1} \mathrm{~K}^{-1}$, we obtain from our measured $\Delta G^{\circ}, \Delta H^{\circ}=-17.8 \mathrm{kcal} \mathrm{mol}^{-1}$, in excellent agreement with the earlier value obtained by Meot-Ner et al. ${ }^{32}$

Using the R2PI of benzene, we also measured the benzene ${ }^{+} /$toluene charge transfer and the toluene ${ }^{+} /(\text {toluene })_{2}{ }^{+}$equilibria. For these systems, we obtain $\Delta G^{\circ}(298 \mathrm{~K})$ of $-10.5 \pm 0.2 \mathrm{kcal} \mathrm{mol}^{-1}$ and $-7.5 \pm 0.2$ $\mathrm{kcal} \mathrm{mol}^{-1}$ for the charge transfer and for the (toluene) ${ }_{2}^{+}$ association, respectively. $\Delta G^{\circ}(298 \mathrm{~K})$ values for the formation of $\mathrm{C}_{6} \mathrm{H}_{6}{ }^{+\bullet}\left(\mathrm{CH}_{3} \mathrm{CN}\right), \quad \mathrm{C}_{6} \mathrm{H}_{6}{ }^{+\bullet}\left(\mathrm{CH}_{3} \mathrm{CN}\right)_{2}$, $\mathrm{C}_{6} \mathrm{H}_{6}{ }^{+\bullet}\left(\mathrm{CH}_{3} \mathrm{COOC}_{2} \mathrm{H}_{5}\right)$ and $\left(\mathrm{C}_{6} \mathrm{H}_{5} \mathrm{CH}_{3}\right)_{2}{ }^{+\bullet}$ were also measured and the results are given in Table I. For the first three systems, we estimate $\Delta S^{\circ}$ as $-22.0 \mathrm{cal} \mathrm{mol}^{-1} \mathrm{~K}^{-1}$ based on the literature values of similar systems. ${ }^{34}$ For example, for all known clusters of this type, $\Delta S^{\circ}$ is in the range $24 \pm 4$ cal mol ${ }^{-1} \mathrm{~K}^{-1} \cdot 16,34$ The uncertainty introduced by $T \Delta S^{\circ}$ to calculate $\Delta H^{\circ}$ from $\Delta G^{\circ}=\Delta H^{\circ}-T \Delta S^{\circ}$, at $300 \mathrm{~K}$ is \pm 1.2 $\mathrm{kcal} \mathrm{mol}^{-1}$, comparable with the uncertainty usually obtained with direct $\Delta H^{\circ}$ measurements from Van't Hoff plots. The resulting estimates of the $\Delta H^{\circ}$ for the studied systems are also given in Table I.

\section{B. Proton transfer reactions}

In this section we present the results of the proton transfer reactions involving benzene or toluene radical cations $\left(\mathrm{X}^{+\bullet}\right)$ with several polar molecules (S). In all cases, the benzene cations are generated by resonance excitation with the wavelength fixed at the benzene $6_{0}^{1}$ absorption maximum $\left(258.85 \mathrm{~nm}\right.$, Fig. 1). For toluene ${ }^{+\bullet}$ reactions, the toluene cations are generated via the exothermic charge transfer from benzene $^{+\bullet}$.

The temporal profile for each of the reactant and the product ions is obtained by averaging the ion signal over the time period $(0-10 \mathrm{~ms}, \Delta t=5 \mu \mathrm{s})$ following the laser pulse. The kinetics for each $\mathrm{X}^{+\bullet} / \mathrm{S}$ system were analyzed by simulation of the ion temporal profiles. ${ }^{35}$ The overall mechanism used is shown below (Eq. 2). The simulation parameters are the pseudo first order rate constants $\left(v_{ \pm i}\right)$. Association and ligand exchange reactions are reversible $\left(v_{ \pm 1}, v_{ \pm 2}\right.$, and $\left.v_{ \pm 3}\right)$ and the proton transfer reactions $\left(v_{\mathrm{T}}\right.$ and $v_{\mathrm{S}}$ denote the rates of termolecular and switching reactions, respectively) are irreversible. Thus, it is assumed that the proton exchange may occur from either the $\mathrm{X}^{+\bullet}$ channel, the $\mathrm{X}^{+\bullet} \mathrm{S}$ channel, or both.

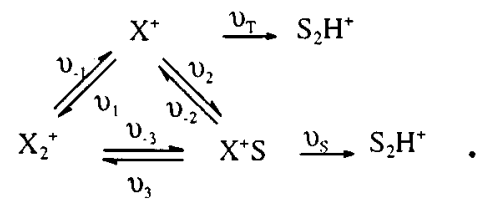

It should be noted that in view of the small probability for simultaneous three-body collisions involving the $\mathrm{X}^{+}$ radical cation and two $\mathrm{S}$ molecules, it appears that the overall mechanism must always involve the $\mathrm{X}^{+\bullet} \mathrm{S}$ cluster followed by collision with a second $\mathrm{S}$ molecule. However, we distinguish between two cases. First, if the product $\mathrm{S}_{2} \mathrm{H}^{+}$is formed via a slow switching reaction of the stabilized $\mathrm{X}^{+\bullet} \mathrm{S}$ cluster, then the $\mathrm{X}^{+} \cdot \mathrm{S}$ cluster is actually observed and the rate is controlled by the second bimolecular switching step. We refer to this process as bimolecular switching $\left(k_{\mathrm{S}}\right)$. Second, if the formation of $\mathrm{X}^{+\bullet} \mathrm{S}$ is too slow and the switching reaction 
TABLE II. Thermochemical properties of compounds investigated. $-\Delta H_{0,1}^{\circ}$ is the association energy of the proton bound solvent dimer, $\mathrm{SH}^{+}+\mathrm{S} \rightarrow \mathrm{S}_{2} \mathrm{H}^{+}$where $\mathrm{S}=\mathrm{CH}_{3} \mathrm{CN}, \mathrm{CH}_{3} \mathrm{OH}, \mathrm{C}_{2} \mathrm{H}_{5} \mathrm{OH}$ and $\mathrm{CH}_{3} \mathrm{COOC}_{2} \mathrm{H}_{5}$.

\begin{tabular}{|c|c|c|c|c|}
\hline Compound & $\begin{array}{l}\text { Dipole moment } \\
\mu(\text { Debye })^{\mathrm{a}}\end{array}$ & $\begin{array}{l}\text { Ionization potential } \\
\left(\mathrm{kcal} \mathrm{mol}^{-1}\right)^{\mathrm{b}}\end{array}$ & $\begin{array}{l}\text { Proton affinity } \\
\left(\mathrm{kcal} \mathrm{mol}^{-1}\right)^{\mathrm{c}}\end{array}$ & $\begin{array}{c}-\Delta H_{0,1}^{\circ} \\
\left(\mathrm{kcal} \mathrm{mol}^{-1}\right)^{\mathrm{d}}\end{array}$ \\
\hline $\mathrm{CH}_{3} \mathrm{CN}$ & 3.90 & 281.8 & 188.4 & 30.2 \\
\hline $\mathrm{CH}_{3} \mathrm{OH}$ & 1.70 & 250.4 & 181.9 & 32.6 \\
\hline $\mathrm{C}_{2} \mathrm{H}_{5} \mathrm{OH}$ & 1.69 & 242.3 & 188.3 & 32.1 \\
\hline $\mathrm{CH}_{3} \mathrm{COOC}_{2} \mathrm{H}_{5}$ & 1.78 & 233.5 & 200.7 & 30.0 \\
\hline $\mathrm{H}_{2} \mathrm{O}$ & 1.85 & 291.1 & 166.5 & 31.6 \\
\hline $\mathrm{C}_{6} \mathrm{H}_{6}$ & 0.00 & 213.7 & 181.0 & \\
\hline $\mathrm{C}_{6} \mathrm{H}_{5} \mathrm{CH}_{3}$ & 0.36 & 203.3 & 189.8 & \\
\hline $\mathrm{C}_{6} \mathrm{H}_{5}^{-}$ & & & 211 & \\
\hline $\mathrm{C}_{6} \mathrm{H}_{5} \mathrm{CH}_{2}^{-}$ & & & 199.2 & \\
\hline
\end{tabular}

of $\mathrm{X}^{+\bullet} \mathrm{S}$ is too fast to observe the stabilized $\mathrm{X}^{+\bullet} \mathrm{S}$ cluster, then the kinetics are equivalent to a termolecular reaction. We refer to the generation of $\mathrm{S}_{2} \mathrm{H}^{+}$by this mechanism as a termolecular process $\left(k_{\mathrm{T}}\right)$ occurring directly from $\mathrm{X}^{+\bullet}$. The rate constants are obtained by dividing the observed firstorder rate constants by $[\mathrm{N}]_{\mathrm{S}}$ or $[\mathrm{N}]_{\mathrm{S}}^{2}$, where $[\mathrm{N}]_{\mathrm{S}}$ is the number density of $\mathrm{S}$ in the ion source, corresponding to the mechanism that applies.

$$
\frac{v_{\mathrm{S}}}{[\mathrm{N}]_{\mathrm{S}}}=k_{\mathrm{S}} ; \quad \frac{v_{\mathrm{T}}}{[\mathrm{N}]_{\mathrm{S}}^{2}}=k_{\mathrm{T}} .
$$

Furthermore, once the proton bound dimer $\mathrm{S}_{2} \mathrm{H}^{+}$is formed, it may undergo further solvation according to:

$$
\mathrm{S}_{2} \mathrm{H}^{+}+\mathrm{S} \rightarrow \mathrm{S}_{3} \mathrm{H}^{+}+\mathrm{S} \rightarrow \mathrm{S}_{4} \mathrm{H}^{+}+\mathrm{S} \rightarrow \text { etc. }
$$

In the analysis, all of the observed $\mathrm{S}_{n} \mathrm{H}^{+}$ions $(n \geqslant 2)$ are summed together. The parameters are adjusted iteratively until a reasonable fit with the experimental data is obtained. In each time profile shown (Figs. 3-7), the smooth lines are the results of the simulation and the rough lines (points) represent the experimental data. The thermochemical properties and the rate constants determined for systems studied are listed in Tables II and III, respectively. In the following sections, we present both the measured and simulated data for each individual system.

TABLE III. Rate coefficients $(298 \mathrm{~K})$ for proton transfer reactions. $k_{\mathrm{S}}$ and $k_{\mathrm{T}}$ denote the rate coefficients for the bimolecular switching: $X^{+\bullet} \mathrm{S}+\mathrm{S} \rightarrow \mathrm{S}_{2} \mathrm{H}^{+}+(\mathrm{X}-\mathrm{H})^{\bullet}$ and the direct termolecular: $\mathrm{X}^{+\bullet}+2 \mathrm{~S} \rightarrow \mathrm{S}_{2} \mathrm{H}^{+}+(\mathrm{X}-\mathrm{H})^{\bullet}$ reactions, respectively. $\Delta \mathrm{PA}$ is the difference in proton affinities where: $\Delta \mathrm{PA}=\mathrm{PA}(\mathrm{X}-\mathrm{H})^{\circ}-\mathrm{PA}(2 \mathrm{~S}) ; \quad \mathrm{PA}(2 \mathrm{~S})=\Delta \mathrm{H}^{\circ}$ $\left(\mathrm{H}^{+}+2 \mathrm{~S} \rightarrow \mathrm{S}_{2} \mathrm{H}^{+}\right)=\mathrm{PA}(\mathrm{S})+\Delta \mathrm{H}^{\circ}\left(\mathrm{S}_{2} \mathrm{H}^{+} \rightarrow \mathrm{SH}^{+}+\mathrm{S}\right)$.

\begin{tabular}{llccr}
\hline \hline \multicolumn{1}{c}{$\mathrm{X}$} & \multicolumn{1}{c}{$\mathrm{S}$} & $\begin{array}{c}k_{\mathrm{S}} \\
\mathrm{cm}^{3} \mathrm{~s}^{-1}\end{array}$ & $\begin{array}{c}k_{\mathrm{T}} \\
\mathrm{cm}^{6} \mathrm{~s}^{-1}\end{array}$ & $\begin{array}{c}\Delta \mathrm{PA} \\
\mathrm{kcal} \mathrm{mol}^{-1}\end{array}$ \\
\hline $\mathrm{C}_{6} \mathrm{H}_{6}$ & $\mathrm{CH}_{3} \mathrm{CN}$ & $1.6 \pm 1.0 \times 10^{-13}$ & $4.9 \pm 1.0 \times 10^{-28}$ & -7.6 \\
$\mathrm{C}_{6} \mathrm{H}_{6}$ & $\mathrm{CH}_{3} \mathrm{OH}$ & - & $3.0 \pm 1.0 \times 10^{-27}$ & -3.5 \\
$\mathrm{C}_{6} \mathrm{H}_{6}$ & $\mathrm{C}_{2} \mathrm{H}_{5} \mathrm{OH}$ & - & $2.5 \pm 0.5 \times 10^{-26}$ & -9.4 \\
$\mathrm{C}_{6} \mathrm{H}_{6}$ & $\mathrm{CH}_{3} \mathrm{COOC} \mathrm{H}_{5}$ & $5.3 \pm 1.0 \times 10^{-12}$ & - & -19.7 \\
& & - & $8.2 \pm 0.5 \times 10^{-28}$ & -15.3 \\
$\mathrm{C}_{6} \mathrm{H}_{5} \mathrm{CH}_{3}$ & $\mathrm{CH}_{3} \mathrm{OH}$ & - & $3.7 \pm 0.5 \times 10^{-27}$ & -21.2 \\
$\mathrm{C}_{6} \mathrm{H}_{5} \mathrm{CH}_{3}$ & $\mathrm{C}_{2} \mathrm{H}_{5} \mathrm{OH}$ & - & - & +1.6 \\
$\mathrm{C}_{6} \mathrm{H}_{5} \mathrm{CH}_{3}$ & $\mathrm{H}_{2} \mathrm{O}$ & - & - & +1.6 \\
\hline \hline
\end{tabular}

\section{Benzene ${ }^{+}$-acetonitrile $\left(B^{+\cdot} / A\right)$}

The R2PI-HPMS mass spectrum obtained for a mixture of benzene (B) and acetonitrile (A) in $\mathrm{N}_{2}$ carrier gas $\left(P_{\text {total }}=0.44\right.$ Torr $)$ at $298 \mathrm{~K}$ is shown in Fig. 2. Under these conditions the species involved in the monomer/dimer ion equilibria $\left(\mathrm{B}^{+\bullet} / \mathrm{B}_{2}^{+\bullet}\right.$ and $\left.\mathrm{B}^{+\bullet} / \mathrm{B}^{+\bullet} \mathrm{A}\right)$ dominate the mass spectrum. Also observed in small intensities are the two mixed trimer ions, $\mathrm{B}^{+\bullet} \mathrm{A}_{2}(\mathrm{~m} / \mathrm{z} 160)$ and $\mathrm{B}_{2}{ }^{+\bullet} \mathrm{A}(\mathrm{m} / \mathrm{z} 197)$. The peak that appears at $\mathrm{m} / \mathrm{z} 83$ has been assigned to the proton bound acetonitrile dimer $\left(\mathrm{AH}^{+} \mathrm{A}\right)$. As indicated from the photoabsorption spectrum (Fig. 1d), the origin of $\mathrm{A}_{2} \mathrm{H}^{+}$is clearly through the $6_{0}^{1}$ resonance ionization of benzene. Isotopic experiments using $\mathrm{CD}_{3} \mathrm{CN}$ and $\mathrm{C}_{6} \mathrm{H}_{6}$ result in the formation of $\left(\mathrm{CD}_{3} \mathrm{CN}\right)_{2} \mathrm{H}^{+}$and not $\left(\mathrm{CD}_{3} \mathrm{CN}\right)_{2} \mathrm{D}^{+}$thus confirming that the origin of the proton must be the benzene radical

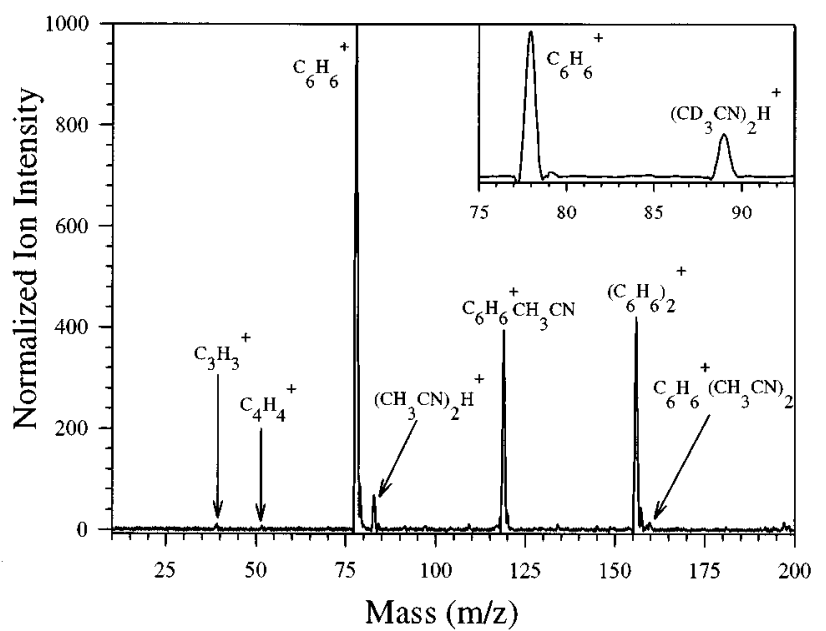

FIG. 2. R2PI-HPMS mass spectrum obtained for a mixture of $0.1 \%$ benzene $\left(\mathrm{C}_{6} \mathrm{H}_{6}\right)$ and $8.0 \%$ acetonitrile $\left(\mathrm{CH}_{3} \mathrm{CN}\right)$ in $\mathrm{N}_{2}$ carrier gas $(0.20$ Torr $)$ at $298 \mathrm{~K}$ and $\lambda=258.85 \mathrm{~nm}$. The insert shows the reaction products for a $\mathrm{C}_{6} \mathrm{H}_{6}$ and $\mathrm{CD}_{3} \mathrm{CN}$ mixture 


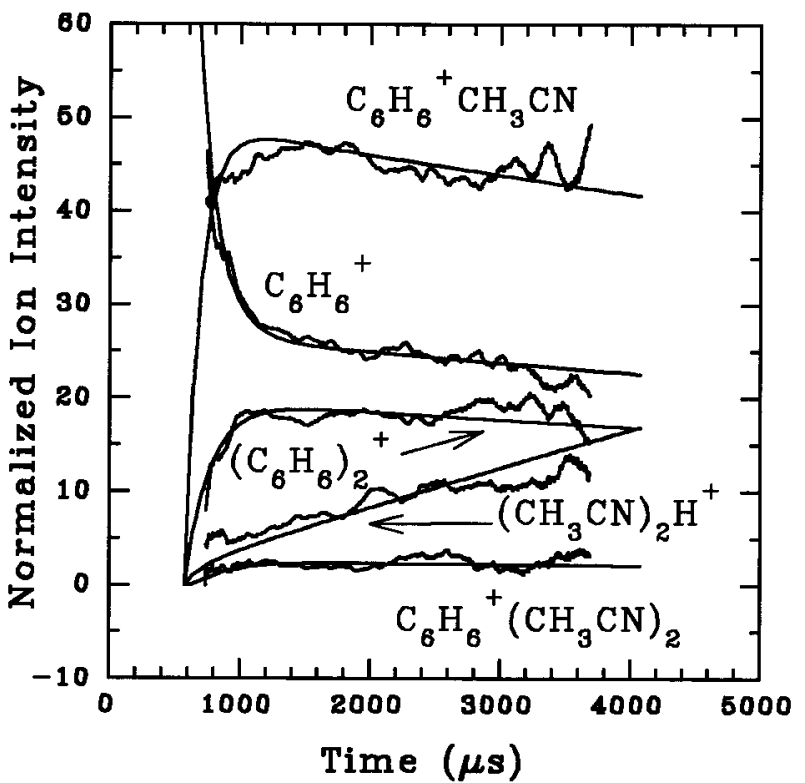

FIG. 3. Temporal profiles obtained for benzene $\left(\mathrm{C}_{6} \mathrm{H}_{6}\right)$ /acetonitrile $\left(\mathrm{CH}_{3} \mathrm{CN}\right)$ system. Source pressure is 0.76 Torr in $\mathrm{N}_{2}$ with $0.01 \%$ benzene and $1.80 \%$ acetonitrile at $298 \mathrm{~K}$ and $\lambda=258.85 \mathrm{~nm}$. The smooth lines are the results of the simulation and the rough lines (points) represent the experimental data.

cation, $\mathrm{C}_{6} \mathrm{H}_{6}{ }^{+}$or one of its fragments $\left(\mathrm{C}_{3} \mathrm{H}_{3}{ }^{+}\right.$or $\left.\mathrm{C}_{4} \mathrm{H}_{4}{ }^{+}\right)$. However, the relative intensity of the $\mathrm{A}_{2} \mathrm{H}^{+}$ion is much greater than the total ion current for these fragments as shown in Fig. 2. Furthermore, we have also carried out experiments under high laser fluences to enhance the fragmentation of $\mathrm{C}_{6} \mathrm{H}_{6}{ }^{+\bullet}$ through the absorption of a third photon, but the increased ion intensity of the fragments did not result in a corresponding increase in the intensity of the $\mathrm{A}_{2} \mathrm{H}^{+}$ion. Additionally, the $\mathrm{AH}^{+}$ion has not been observed in any of these experiments. Therefore, the possibility of a direct proton transfer from a fragment ion to $\mathrm{CH}_{3} \mathrm{CN}$ can be convincingly eliminated.

Figure 3 shows that the $\mathrm{B}^{+\bullet} / \mathrm{B}_{2}{ }^{+\bullet} / \mathrm{B}^{+\bullet} \mathrm{A}$ equilibrium is established quickly and shifted toward $\mathrm{B}^{+\bullet} \mathrm{A}$. From the equilibrium ion intensity ratio, we obtain $\Delta G^{\circ}$ for the association of $\mathrm{B}^{+\bullet} \mathrm{A}$ as $\Delta G^{\circ}(298)=-7.1 \pm 0.2 \mathrm{kcal} \mathrm{mol}^{-1}$ and hence we estimate $\Delta H^{\circ}$ as $-13.7 \mathrm{kcal} \mathrm{mol}-1$ (assuming $\Delta S^{\circ}$ as -22 cal $\left.\mathrm{mol}^{-1} \mathrm{~K}^{-1}\right){ }^{34}$ The $\mathrm{B}^{+\bullet} \mathrm{A}_{2}$ cluster has also been observed and gives $\Delta G^{\circ}(298)$ of $4.8 \pm 0.2 \mathrm{kcal} \mathrm{mol}^{-1}$ which results in an estimate of $\Delta H^{\circ}\left(11.4 \mathrm{kcal} \mathrm{mol}^{-1}\right)$ for the dissociation to $\mathrm{B}^{+\bullet} \mathrm{A}+\mathrm{A}$. The formation of $\mathrm{A}_{2} \mathrm{H}^{+}$from $\mathrm{B}^{+} \mathrm{A}$ (i.e. $\mathrm{B}^{+\bullet} \mathrm{A}+\mathrm{A} \rightarrow \mathrm{A}_{2} \mathrm{H}^{+}+\mathrm{C}_{6} \mathrm{H}_{5}{ }^{\cdot}$ where $\mathrm{A}$ is acetonitrile and $\mathrm{B}$ is benzene) is endothermic by $6.1 \mathrm{kcal} \mathrm{mol}^{-1}$. Equating this with an activation energy, Arrhenius theory predicts a reaction rate of $6.4 \times 10^{-14} \mathrm{~cm}^{3} \mathrm{~s}^{-1}$ as compared to the measured rate of $k_{\mathrm{S}}=1.6 \times 10^{-13} \mathrm{~cm}^{3} \mathrm{~s}^{-1}$. The simulations of the temporal profiles result in rate constants for the bimolecular switching $\left(\mathrm{B}^{+\cdot} \mathrm{A}+\mathrm{A} \rightarrow \mathrm{A}_{2} \mathrm{H}^{+}+\mathrm{C}_{6} \mathrm{H}_{5}{ }^{\circ}\right)$ or the direct termolecular $\left(\mathrm{B}^{+\cdot}+2 \mathrm{~A} \rightarrow \mathrm{A}_{2} \mathrm{H}^{+}+\mathrm{C}_{6} \mathrm{H}_{5}{ }^{\circ}\right)$ as $1.6 \times 10^{-13} \mathrm{~cm}^{3} \mathrm{~s}^{-1}$ or $4.9 \times 10^{-28} \mathrm{~cm}^{6} \mathrm{~s}^{-1}$, respectively. Clearly, in both cases the reaction is quite inefficient.

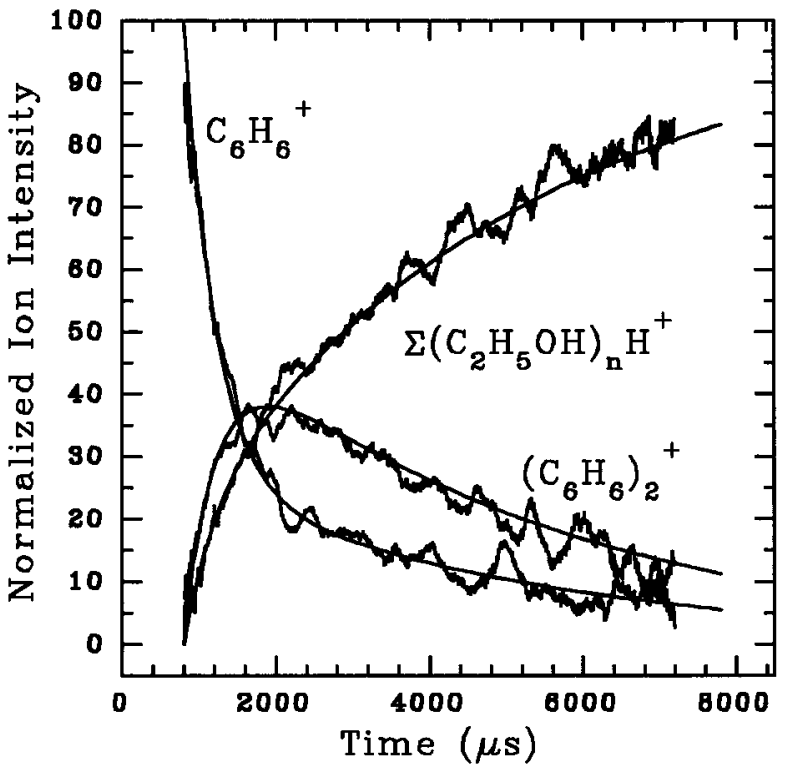

FIG. 4. Temporal profiles for benzene $\left(\mathrm{C}_{6} \mathrm{H}_{6}\right) /$ ethanol $\left(\mathrm{C}_{2} \mathrm{H}_{5} \mathrm{OH}\right)$ system. Source pressure is 0.77 Torr in $\mathrm{Ar}$ with $0.02 \%$ benzene and $0.40 \%$ ethanol at $298 \mathrm{~K}$ and $\lambda=258.85 \mathrm{~nm}$. The smooth lines are the results of the simulation and the rough lines (points) represent the experimental data. $\Sigma\left(\mathrm{C}_{2} \mathrm{H}_{5} \mathrm{OH}\right)_{n} \mathrm{H}^{+}$represents the protonated ethanol series observed with $n=2-4$.

\section{Benzene ${ }^{+}$-methanol $\left(B^{+\bullet} / M\right)$}

In this system, the generation of $\mathrm{M}_{2} \mathrm{H}^{+}$from the direct

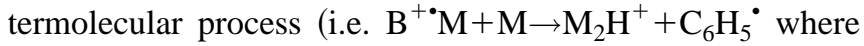
$\mathrm{M}$ is methanol and $\mathrm{B}$ is benzene) is slightly exothermic $\left(-3.5 \mathrm{kcal} \mathrm{mol}^{-1}\right){ }^{36}$ In the experiments, the stabilized ad-

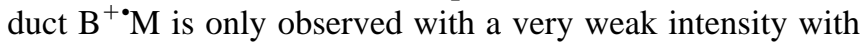
the predominant ions being the protonated methanol clusters $\mathrm{M}_{n} \mathrm{H}^{+}(n=2-4)$. The direct termolecular rate is determined as $k_{\mathrm{T}}=3.0 \times 10^{-27} \mathrm{~cm}^{6} \mathrm{~s}^{-1}$, which indicates that $k_{\mathrm{T}}$ for $\left(\mathrm{B}^{+\bullet} / \mathrm{M}\right)>k_{\mathrm{T}}$ for $\left(\mathrm{B}^{+\bullet} / \mathrm{A}\right)$ in spite of the latter system being more exothermic. This suggests that the reaction efficiency may be influenced by structural factors in addition to thermochemistry. This point will become more apparent by comparing the alcohol systems with the acetonitrile and ethyl acetate systems.

\section{Benzene ${ }^{+}$-ethanol $\left(B^{+*} / E\right)$}

This system (Fig. 4) is dominated by the presence of protonated ethanol clusters $\mathrm{E}_{n} \mathrm{H}^{+}$(where $\mathrm{E}$ is ethanol and $n=2-4)$. In addition, no stable benzene ${ }^{+\bullet} /$ ethanol binary cluster $\left(\mathrm{B}^{+\cdot} \mathrm{E}\right)$ is observed. The simulations show that all of the $\mathrm{E}_{n} \mathrm{H}^{+}$intensity can be accounted for through the termolecular pathway $\left(v_{\mathrm{T}}\right)$. The measured rate $\left(v_{\mathrm{T}}\right)$ increases linearly with the square of the partial pressure of ethanol in the ion source. The absence of a stabilized $\mathrm{B}^{+\bullet} \mathrm{E}$ cluster indicates that the $\mathrm{B}^{+\bullet} \mathrm{E}$ binary cluster reacts rapidly with a second ethanol molecule, and hence the process is equivalent to a direct termolecular mechanism for this system. 


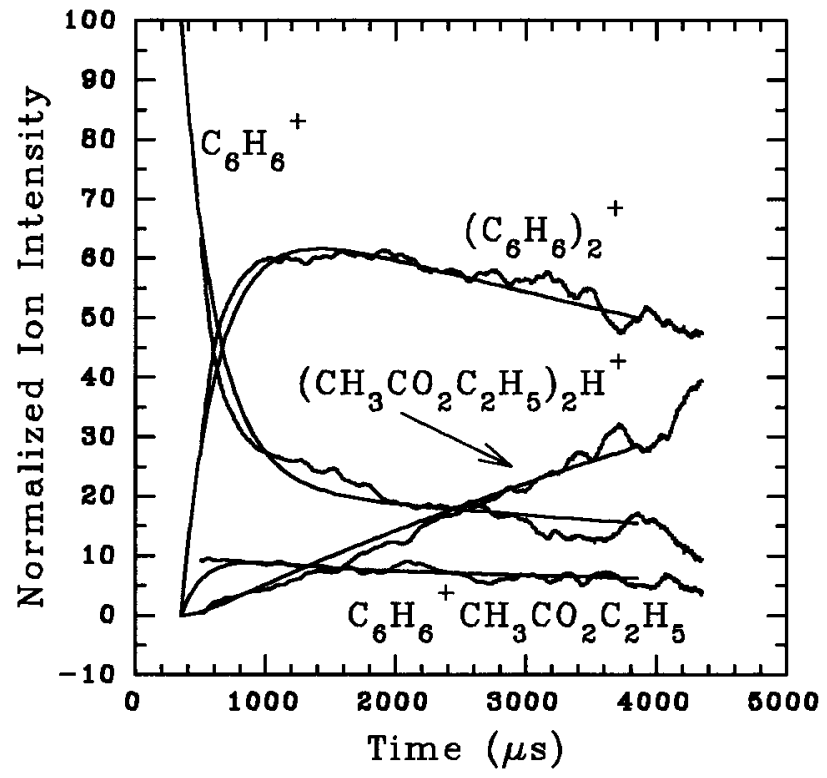

FIG. 5. Temporal profiles for benzene $\left(\mathrm{C}_{6} \mathrm{H}_{6}\right)$ /ethyl acetate $\left(\mathrm{CH}_{3} \mathrm{COOC}_{2} \mathrm{H}_{5}\right)$ system. Source pressure is 0.66 Torr in Ar with $0.01 \%$ benzene and $1.0 \%$ ethyl acetate at $298 \mathrm{~K}$ and $\lambda=258.85 \mathrm{~nm}$. The smooth lines are the results of the simulation and the rough lines (points) represent the experimental data.

\section{Benzene ${ }^{+}$-ethyl acetate $\left(B^{+*} / E A c\right)$}

The temporal profiles for benzene/ethyl acetate (EAc) are shown in Fig. 5. The system shows large $\mathrm{B}_{2}{ }^{+\bullet} / \mathrm{B}^{+\bullet}$ and weaker $\mathrm{B}^{+\bullet} \mathrm{EAc} / \mathrm{B}^{+\bullet}$ adducts in equilibrium where $\mathrm{B}$ and EAc denote benzene and ethyl acetate, respectively. The simulations reveal that the ion intensity of $(\mathrm{EAc})_{2} \mathrm{H}^{+}$is modeled primarily through the switching reaction of $\mathrm{B}^{+{ }^{*}} \mathrm{EAc}\left(v_{\mathrm{S}}\right)$ at a rate of $k_{\mathrm{S}}=5.3 \times 10^{-12} \mathrm{~cm}^{3} \mathrm{~s}^{-1}$. The switching pathway is characterized by a delay in the initial build of $(\mathrm{EAc})_{2} \mathrm{H}^{+}$ and a dependence of the overall build-up on the $\mathrm{B}^{+{ }^{\circ}} \mathrm{EAc}$ adduct. From the simulation results, the exchange reactions $\left(v_{3} / v_{3}\right)$ are generally faster than the association reactions $\left(v_{1} / v_{-1}, v_{2} / v_{-2}\right)$ and the build-up of the reaction precursor $\mathrm{B}^{+\bullet} \mathrm{EAc}$ is limited by the exchange channel $\left(\mathrm{B}^{+\cdot} \mathrm{EAc}+\mathrm{B}\right.$ $=\mathrm{B}_{2}{ }^{+}+\mathrm{EAc}$ ). The decrease in $\mathrm{B}_{2}{ }^{+\bullet}$ in time is a result of the equilibrium shifting to accommodate the formation of the $(\mathrm{EAc})_{2} \mathrm{H}^{+}$product which irreversibly depletes the precursor ion, $\mathrm{B}^{+\cdot}$ EAc.

\section{Toluene ${ }^{+}$-methanol $\left(T^{+\bullet} / M\right)$}

The ion time profiles for the benzene (B)-toluene (T)methanol (M) system are shown in Fig. 6. In contrast to the benzene ${ }^{+} /$methanol (where the $\mathrm{B}_{2}{ }^{+\cdot}$ ion is significant), the toluene ${ }^{+} /$methanol system does not have significant contributions from the toluene ${ }_{2}{ }^{+\bullet}$ ion. The dominant reaction is $\mathrm{T}^{+\bullet}+2 \mathrm{M} \rightarrow \mathrm{M}_{2} \mathrm{H}^{+}+\mathrm{C}_{7} \mathrm{H}_{7}{ }^{\cdot}$ followed by the formation of $\mathrm{M}_{n} \mathrm{H}^{+}$with $n=3-5$. The $\mathrm{M}_{n} \mathrm{H}^{+}$equilibrium is shifted toward $\mathrm{M}_{4} \mathrm{H}^{+}$and no stable $\mathrm{T}^{+\bullet} \mathrm{M}$ cluster is observed.

\section{Toluene ${ }^{+}$-ethanol $\left(T^{+*} / E\right)$}

This system (Fig. 7) is dominated by the presence of protonated ethanol clusters $\left(\mathrm{E}_{n} \mathrm{H}^{+}, n=2-4\right)$. In the simula-

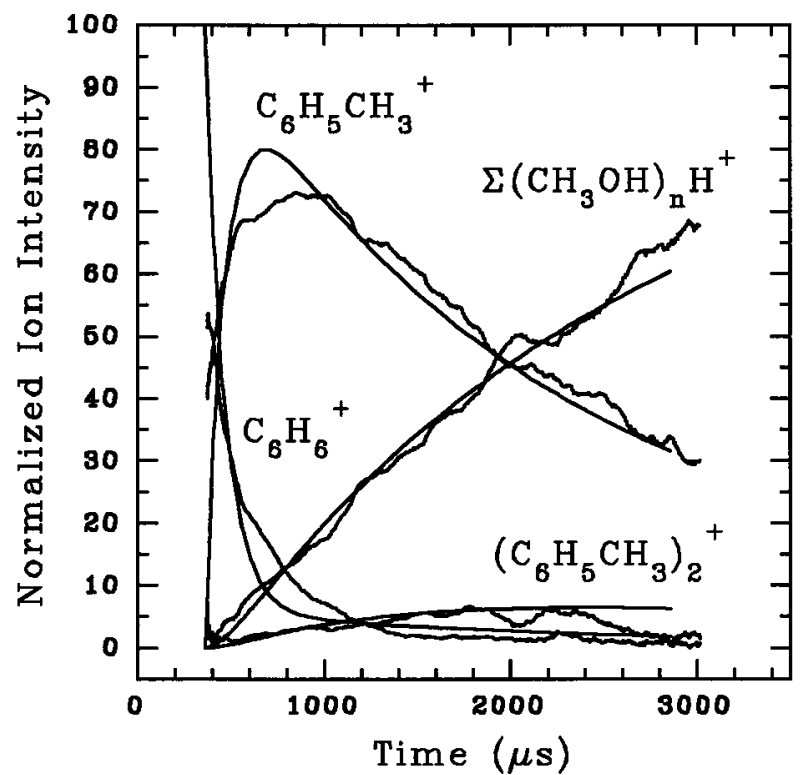

FIG. 6. Temporal profiles for benzene $\left(\mathrm{C}_{6} \mathrm{H}_{6}\right)$, toluene $\left(\mathrm{C}_{6} \mathrm{H}_{5} \mathrm{CH}_{3}\right)$ and methanol $\left(\mathrm{CH}_{3} \mathrm{OH}\right)$ system. Source pressure is 0.50 Torr in Ar with $0.10 \%$ benzene, $0.20 \%$ toluene and $4.7 \%$ methanol at $298 \mathrm{~K}$ and $\lambda=258.85 \mathrm{~nm}$. The smooth lines are the results of the simulation and the rough lines (points) represent the experimental data.

tion, both the toluene ${ }^{+} /$ethanol and the benzene ${ }^{+} /$ethanol proton exchange channels were included. The rates obtained for the benzene ${ }^{+} /$ethanol channel were the same as those obtained from the benzene ${ }^{+}$-ethanol system (in the absence of toluene). Under the conditions used, no stable $\mathrm{T}^{+\bullet} \mathrm{E}$ or

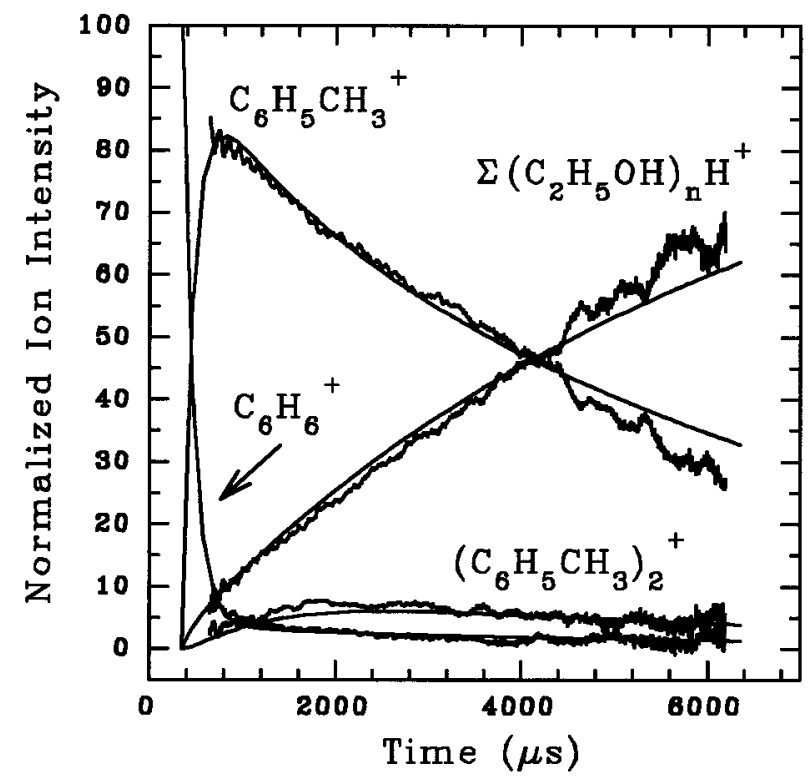

FIG. 7. Temporal profiles for benzene $\left(\mathrm{C}_{6} \mathrm{H}_{6}\right)$, toluene $\left(\mathrm{C}_{6} \mathrm{H}_{5} \mathrm{CH}_{3}\right)$ and ethanol $\left(\mathrm{C}_{2} \mathrm{H}_{5} \mathrm{OH}\right)$ system. Source pressure is 0.84 Torr in $\mathrm{Ar}$ with $0.08 \%$ benzene, $0.16 \%$ toluene and $0.8 \%$ ethanol at $298 \mathrm{~K}$ and $\lambda=258.85 \mathrm{~nm}$. The smooth lines are the results of the simulation and the rough lines (points) represent the experimental data 


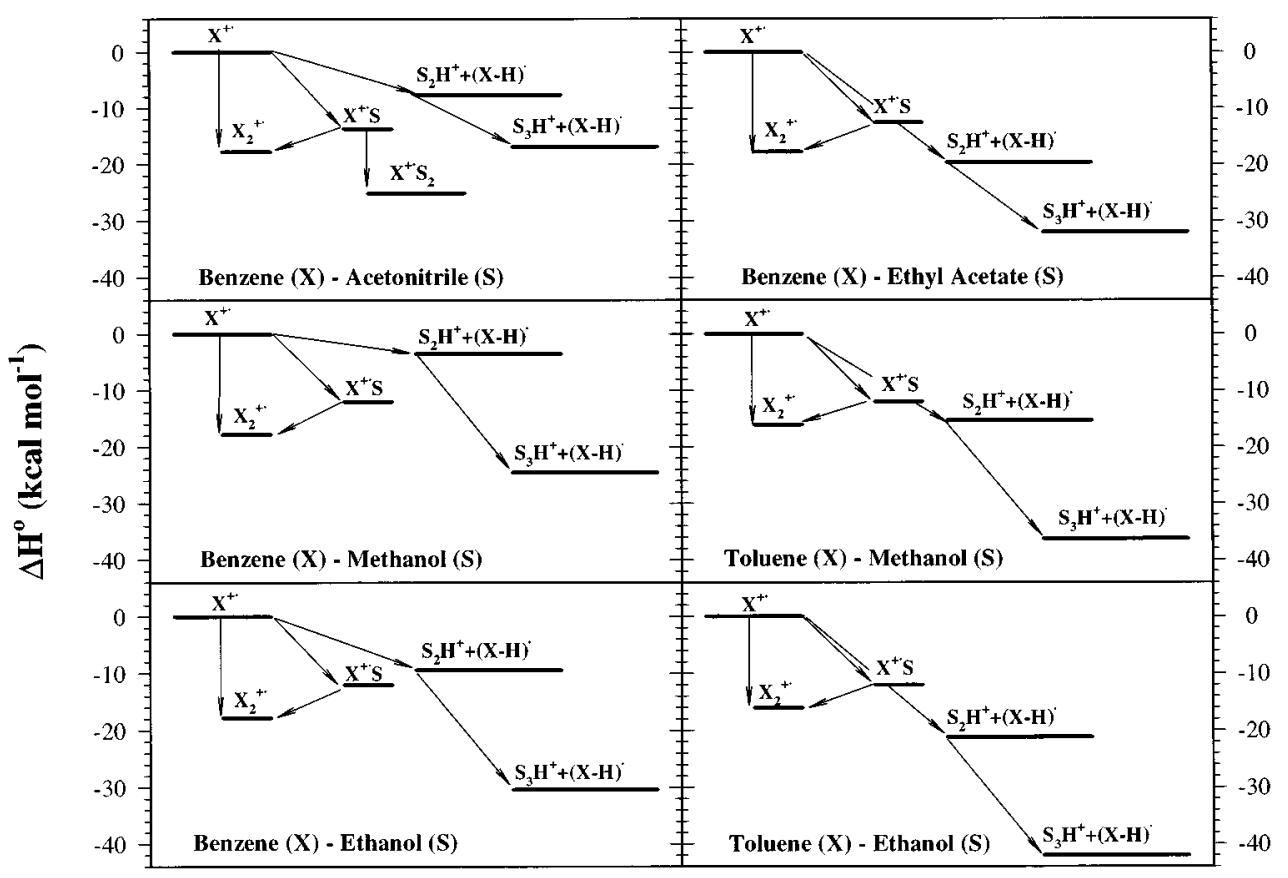

FIG. 8. Energy ladder for the systems investigated ( $\mathrm{X}=$ benzene or toluene, $\mathrm{S}=$ acetonitrile, ethanol, methanol or ethyl acetate). Binding energies for benzene $^{+\cdot}$ ethanol, benzene ${ }^{+\cdot}$ methanol, toluene ${ }^{+\cdot}$ methanol and toluene ${ }^{+\cdot}$ ethanol cluster ions are estimated as $-12 \mathrm{kcal} \mathrm{mol}^{-1}$. $\Delta \mathrm{H}^{\circ}{ }_{1,2}$ for the reaction $\mathrm{S}_{2} \mathrm{H}^{+}+\mathrm{S} \rightarrow \mathrm{S}_{3} \mathrm{H}^{+}$are estimated as $-21 \mathrm{kcal} \mathrm{mol}^{-1}$ for $\mathrm{S}=$ ethanol and $-12 \mathrm{kcal} \mathrm{mol}^{-1}$ for $\mathrm{S}=$ ethyl acetate. All other values from Tables I-III and Ref. 16 .

$\mathrm{B}^{+\bullet} \mathrm{E}$ clusters are observed. The measured termolecular rate for the toluene ${ }^{+} /$ethanol channel is $3.7 \pm 0.5 \times 10^{-27} \mathrm{~cm}^{6} \mathrm{~s}^{-1}$.

\section{Benzene ${ }^{+}$-water $\left(B^{+\bullet} / W\right)$ and toluene ${ }^{+}$-water $\left(T^{+\bullet} / W\right)$}

In these systems the termolecular reactions generating $\mathrm{W}_{2} \mathrm{H}^{+} \quad$ (i.e., $\quad \mathrm{B}^{+\cdot}+2 \mathrm{~W} \rightarrow \mathrm{W}_{2} \mathrm{H}^{+}+\mathrm{C}_{6} \mathrm{H}_{5}^{\cdot}$ or $\mathrm{T}^{+\cdot}+2 \mathrm{~W}$ $\rightarrow \mathrm{W}_{2} \mathrm{H}^{+}+\mathrm{C}_{7} \mathrm{H}_{7}^{-}$where $\mathrm{W}$ is water) are endothermic by $+12.9 \mathrm{kcal} \mathrm{mol}^{-1}$ and $+1.6 \mathrm{kcal} \mathrm{mol}{ }^{-1}$, respectively. ${ }^{36} \mathrm{In}$ both systems, no protonated water clusters $\left(\mathrm{W}_{n} \mathrm{H}^{+}\right.$for any $\left.n\right)$ are observed. Also, no stable adducts $\left(\mathrm{B}^{+\bullet} \mathrm{W}\right)$ or $\left(\mathrm{T}^{+\bullet} \mathrm{W}\right)$ are detected within our sensitivity limits and under the conditions of the present experiments $\left(T=298 \mathrm{~K}, P_{\text {total }}=0.2-3\right.$ Torr and $0.1-5 \% \mathrm{H}_{2} \mathrm{O}$ in $\mathrm{N}_{2}$ ).

\section{Discussion of reaction mechanisms}

The relative energetics of the reactions investigated are illustrated in Fig. 8. Based on the energetics of the benzene $^{+}-\mathrm{S}$ systems, acetonitrile and ethanol should have the same reaction efficiency $\left(\Delta \mathrm{PA}=-7.6\right.$ and $-9.4 \mathrm{kcal} \mathrm{mol}^{-1}$, respectively), which is less than the efficiency of ethyl acetate $\left(\triangle \mathrm{PA}=-19.7 \mathrm{kcal} \mathrm{mol}^{-1}\right)$. The results show that the ethanol system is by far the most reactive, followed by ethyl acetate and then methanol and acetonitrile. Based on the structures of the solvent molecules, we can compare the reactions involving alcohols where extended $\mathrm{H}$-bonded chains can be formed with the reactions involving acetonitrile and ethyl acetate where blocked protonated dimers are formed.

In view of the strong dipole moment of acetonitrile (3.9 $\mathrm{D}$, Table II), it is reasonable to assume that the structure of the $\mathrm{B}^{+\bullet} \mathrm{A}$ cluster must be the one which maximizes the ion- dipole forces. The T-shaped geometry (I) represents a possible structure where the lone electron pair of the nitrogen is directed toward the center of the benzene cation. The addition of the second acetonitrile molecule to form the $\mathrm{B}^{+\bullet} \mathrm{A}_{2}$ cluster may follow the same principle of maximizing iondipole interaction and structure (II) seems appropriate since the dipoles are still directed toward the cation center, above and below the plane of the benzene ring.

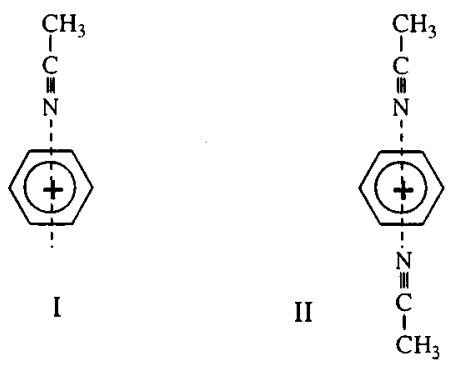

Abstraction of a proton from a benzene cation to form $\mathrm{A}_{2} \mathrm{H}^{+}$requires that the transition state contains strong $\mathrm{A}_{2} \mathrm{H}^{+}$ character leading to the formation of the hydrogen bonded dimer $\left(\mathrm{A}_{2} \mathrm{H}^{+}\right)$and structure III is consistent with such a transition state. This means that the rearrangement of structure II would involve the two acetonitrile molecules shifting toward the localized charge in such a way that $\mathrm{AH}^{+} \mathrm{A}$ begins to form. Therefore, the small efficiency of the proton transfer channel in the $\mathrm{B}^{+\bullet} / \mathrm{A}$ system $\left(10^{-4}\right.$ relative to the collision rate) can be rationalized in terms of an energy barrier for the rearrangement of the stabilized $\mathrm{B}^{+\bullet} \mathrm{A}_{2}$ adduct into the 
$\left(\mathrm{AH}^{+} \mathrm{A}\right)$ structure. This barrier may arise since the transition state requires a sterically hindered structure. A possible structure for the transition state is shown in III.

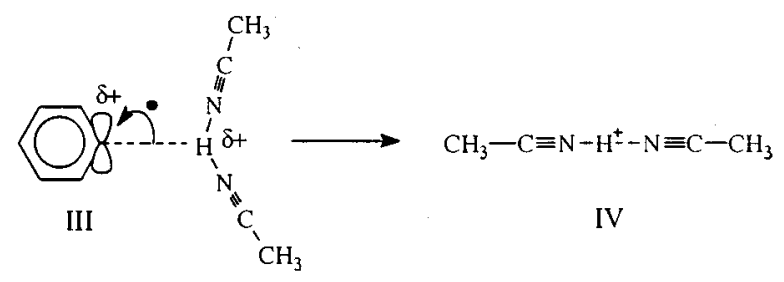

Turning to the ethanol system, the structure of the $\mathrm{B}^{+\cdot} \mathrm{E}$ adduct is expected to involve a hydrogen bond between the oxygen atom and an aromatic hydrogen (Structure V). A structure similar to (I) may not be very likely in view of the smaller and less oriented dipole of ethanol as compared to acetonitrile. Note that Structure V allows the addition of the second ethanol molecule through H-bonding as shown in Structure VI. With this intermediate, the two solvent molecules form a hydrogen-bonded complex that has a proton affinity higher by $25 \mathrm{kcal} / \mathrm{mol}$ than a single ethanol molecule. The cooperative effect of the two solvent molecules allows abstracting the proton from benzene requiring only electron shifts, without the need for a higher energy intermediate.

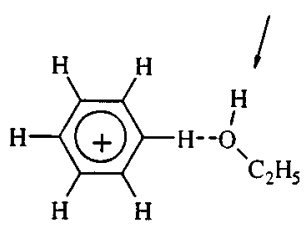

V

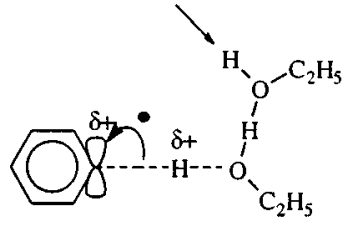

VI
The ethyl acetate system is consistent with the acetonitrile system where the reaction efficiency is decreased by steric crowding at the proton abstraction site. The reaction is however, more efficient than in the acetonitrile system and this can be attributed to the proton exchange step being more exothermic in the ethyl acetate system as shown in Fig. 8.

It is interesting to compare the reaction efficiencies of benzene $^{+}$and toluene ${ }^{+}$toward the alcohol reactants. From the results in Table III, it is clear that the toluene ${ }^{+}$reactions are less efficient. This may suggest that proton abstraction from the $\mathrm{CH}_{3}$ group of toluene is less favorable than from the benzene $^{+}$ring. This behavior is in contrast to the known gas phase acidity of benzene ${ }^{+}$and toluene ${ }^{+} .{ }^{37}$ The difference in the acidities of benzene and toluene radical cations is generally attributed to the difference in the stability of the corresponding phenyl radical ( $\sigma$-radical) and the benzyl radical (resonance stabilized $\pi$-system). The fact that $\mathrm{H}^{+}$abstraction from toluene ${ }^{+}$is not efficient may indicate that in the reaction complexes the solvent molecules are attached to the aromatic, rather than to the methyl hydrogens. This would require a shift of two solvent molecules to less favorable positions in order to extract a proton from the methyl group, which would be an inefficient process.

\section{CONCLUSIONS}

The main conclusions that can be drawn from this study are as follows:

(1) The combination of R2PI with HPMS has been demonstrated for the selective generation of low energy ions and for subsequent kinetic and thermochemical studies with a variety of neutral molecules.

(2) Novel proton transfer reactions from $\mathrm{C}_{6} \mathrm{H}_{6}^{+\cdot}$ to two $\mathrm{CH}_{3} \mathrm{CN}, \mathrm{CH}_{3} \mathrm{OH}, \mathrm{C}_{2} \mathrm{H}_{5} \mathrm{OH}$ and $\mathrm{CH}_{3} \mathrm{COOC}_{2} \mathrm{H}_{5}$ molecules, and from $\mathrm{C}_{6} \mathrm{H}_{5} \mathrm{CH}_{3}^{+\cdot}$ to two $\mathrm{CH}_{3} \mathrm{OH}$ and $\mathrm{C}_{2} \mathrm{H}_{5} \mathrm{OH}$ molecules to form protonated solvent dimers $\left(\mathrm{S}_{2} \mathrm{H}^{+}\right)$ have been observed. The reactions are driven by the strong hydrogen bonds in the $\mathrm{S}_{2} \mathrm{H}^{+}$dimers and therefore require the formation of the hydrogen bond concertedly with proton transfer to make the process energetically feasible. Kinetic simulations suggest that the mechanism proceeds through $\left(\mathrm{C}_{6} \mathrm{H}_{6}^{+\bullet}\right) \mathrm{S}+\mathrm{S} \rightarrow \mathrm{S}_{2} \mathrm{H}^{+}+\mathrm{C}_{6} \mathrm{H}_{5}^{\cdot}$ when this reaction is slow, such as with the blocked reactants $\mathrm{CH}_{3} \mathrm{CN}$ and $\mathrm{CH}_{3} \mathrm{COOC}_{2} \mathrm{H}_{5}$. When this reaction is fast, such as with the alcohol reactants, the $\left(\mathrm{C}_{6} \mathrm{H}_{6}^{+\cdot}\right) \mathrm{S}$ complex is not observed and direct termolecular kinetics apply $\left(\mathrm{C}_{6} \mathrm{H}_{6}^{+\cdot}+2 \mathrm{~S} \rightarrow \mathrm{S}_{2} \mathrm{H}^{+}+\mathrm{C}_{6} \mathrm{H}_{5}^{\cdot}\right.$, although still involving a transient $\left(\mathrm{C}_{6} \mathrm{H}_{6}^{+*}\right) \mathrm{S}$ intermediate). The rate coefficients of these reactions are in the range $10^{-13}-10^{-12} \mathrm{~cm}^{3} \mathrm{~s}^{-1}$ for the reaction through a bimolecular switching channel and in the range of $10^{-26}-10^{-28} \mathrm{~cm}^{6} \mathrm{~s}^{-1}$ for the reaction through a direct termolecular proton extraction mechanism.

(3) The present experiments reveal that no direct correlation exists between the termolecular rate coefficients for the aromatic ${ }^{+}$/solvent systems and the energetics of the proton transfer reactions. The structure of the protonated solvent dimer $\mathrm{S}_{2} \mathrm{H}^{+}$appears to play a significant role in determining the efficiency of the concerted proton transfer process since it influences the involvement of the third solvent molecule which would then make the overall process more energetically favorable. The proton transfer reactions involving alcohols are generally faster than those leading to the formation of blocked H-bonded dimers such as $\mathrm{H}^{+}\left(\mathrm{CH}_{3} \mathrm{CN}\right)_{2}$. The assumption of a hydrogen-bonded chain seems necessary to explain the reactivity of the alcohol systems.

(4) The free energy of association of the benzene dimer cation. $\mathrm{B}_{2}^{+\bullet}$, has been determined as $\Delta G^{\circ}(298 \mathrm{~K})=-9.6$ $\pm 0.2 \mathrm{kcal} \mathrm{mol}^{-1}$ giving an estimate of $\Delta H^{\circ}=-17.8$ $\mathrm{kcal} \mathrm{mol}^{-1}$, in excellent agreement with a previous literature value. The free energy of formation at $298 \mathrm{~K}$ for $\mathrm{C}_{6} \mathrm{H}_{6}^{+\bullet}\left(\mathrm{CH}_{3} \mathrm{CN}\right), \mathrm{C}_{6} \mathrm{H}_{6}^{+\bullet}\left(\mathrm{CH}_{3} \mathrm{CN}\right)_{2}$, $\mathrm{C}_{6} \mathrm{H}_{6}^{+\cdot}\left(\mathrm{CH}_{3} \mathrm{COOC}_{2} \mathrm{H}_{5}\right)$ and $\left(\mathrm{C}_{6} \mathrm{H}_{5} \mathrm{CH}_{3}\right)_{2}^{+\cdot}$ has been measured as $\Delta G^{\circ}(298 \mathrm{~K})=-7.1 \pm 0.2 \mathrm{kcal} \mathrm{mol}^{-1},-4.8$ $\pm 0.2 \mathrm{kcal} \mathrm{mol}^{-1},-6.0 \mathrm{kcal} \mathrm{mol}^{-1}$ and $-7.5 \pm 0.2 \mathrm{kcal}$ $\mathrm{mol}^{-1}$, respectively. The relatively large $\Delta H^{\circ}$ value $\left(-13.7 \mathrm{kcal} \mathrm{mol}^{-1}\right)$ for the $\mathrm{C}_{6} \mathrm{H}_{6}^{+\cdot}\left(\mathrm{CH}_{3} \mathrm{CN}\right)$ cluster, where $\Delta \mathrm{IP}$ is very large $\left(+68.1 \mathrm{kcal} \mathrm{mol}^{-1}\right.$, Table II $)$ 
and no charge-transfer interaction is expected, may reflect the strong ion-dipole interaction in this system.

\section{ACKNOWLEDGMENTS}

The authors gratefully acknowledge financial support from NSF Grant No. CHE 9311643. Acknowledgment is also made to the donors of the Petroleum Research Fund (2764-AC6), administered by the American Chemical Society and to the Thomas F. and Kate Miller Jeffress Memorial Trust for the partial support of this research.

${ }^{1}$ Y. Marcus, Ion Solvation (Wiley, New York, 1985).

${ }^{2}$ The Chemical Physics of Solvation, edited by R. R. Dogonadze, E. Kalman, A. A. Kornyshev, and J. Ullstrup (Elsevier, Amsterdam, 1985), Part A.

${ }^{3}$ B. E. Conway, Ionic Hydration in Chemistry and Biophysics (Elsevier, Amsterdam, 1981)

${ }^{4}$ A. Anne, P. Hapiot, J. Moiroux, P. Neta, and J. M. Saveant, J. Am. Chem. Soc. 114, 4694 (1992).

${ }^{5}$ M. S. Workentin, L. J. Johnston, D. D. M. Wayner, and V. D. Parker, J. Am. Chem. Soc. 116, 8279 (1994).

${ }^{6}$ G. W. Robinson, P. J. Thistlethwaite, and J. Lee, J. Phys. Chem. 90, 4224 (1986).

${ }^{7}$ G. A. Jeffrey and W. Saengeri, in Hydrogen Bonding in Biological Structures (Springer, New York, 1991).

${ }^{8}$ Y. Cha, C. J. Murray, and J. P. Klinman, Science 243, 1325 (1989).

${ }^{9}$ H. Bohringer and F. Arnold, Nature 290, 321 (1981).

${ }^{10}$ D. Smith, N. G. Adams, and E. Alge, Planet. Space Sci. 29, 449 (1981).

${ }^{11}$ D. Kane, G. M. Daly, and M. S. El-Shall, J. Phys. Chem. 99, 7867 (1995).

${ }^{12}$ J. Silverman, S. Tagawa, H. Kobayashi, Y. Katsumura, M. Washio, and Y. Tabata, Radiat. Phys. Chem. 22, 1039 (1983).

${ }^{13}$ T. Gotoh, M. Yamamoto, and Y. Nishijima, J. Polym. Sci. A-1 19, 1047 (1981).

${ }^{14} \mathrm{P}$. Kebarle, in Techniques of Chemistry edited by J. M. Farrar and W. H. Saunders, Jr. (Wiley, New York, 1988), p. 221.

${ }^{15}$ M. Meot-Ner (Mautner), in Gas Phase Ion Chemistry, edited by M. T. Bowers (Academic, New York, 1979), Vol. 1.

${ }^{16}$ R. G. Keesee and A. W. Castleman, Jr., J. Phys. Chem. Ref. Data 15, 1011 (1986).
${ }^{17}$ P. A. M. Van Koppen, P. R. Kemper, A. Illies, and M. T. Bowers, Int. J. Mass Spectrom. Ion Process. 54, 263 (1983).

${ }^{18}$ P. R. Kemper, J. Bushnell, P. V. Koppen, and M. T. Bowers, J. Phys. Chem. 97, 1810 (1993); P. R. Kemper and M. T. Bowers, ibid. 95, 5134 (1991)

${ }^{19}$ D. K. Bohme, G. I. Mackay, and S. D. Tanner, J. Am. Chem. Soc. 101, 3724 (1979); F. C. Fehsenfeld and E. E. Furgeson, J. Chem. Phys. 54, 439 (1971).

${ }^{20}$ W. Y. Feng, M. Iraqi, and C. Liftshitz, J. Phys. Chem. 97, 3510 (1993).

${ }^{21}$ H. J. Neusser and E. W. Schlag, Z. Naturforsch, A 85, 1546 (1981).

${ }^{22}$ E. R. Bernstein, in Atomic and Molecular Clusters, edited by E. R. Bernstein (Elsevier, New York, 1990).

${ }^{23}$ D. M. Lubman, L. Li, J. W. Hager, and S. C. Wallace, in Lasers and Mass Spectrometry, edited by D. M. Lubman (Oxford University, Oxford, 1990).

${ }^{24}$ L. W. Sieck and S. K. Searles, J. Chem. Phys. 53, 2601 (1970).

${ }^{25}$ B. Brutschy, Chem. Rev. 92, 1567 (1992).

${ }^{26}$ E. R. Bernstein, J. Phys. Chem. 96, 10105 (1992).

${ }^{27}$ G. M. Daly and M. S. El-Shall, J. Phys. Chem. 98, 696 (1994).

${ }^{28}$ J. L. Steinfeld, Molecules and Radiation: An Introduction to Modern Molecular Spectroscopy, 2nd ed. (MIT, Cambridge, 1985).

${ }^{29}$ K. Aron, C. Otis, R. E. Demerary, and P. Johnson, J. Chem. Phys. 73, 4167 (1980).

${ }^{30}$ U. Boesl, J. Phys. Chem. 95, 2949 (1991).

${ }^{31}$ S. R. Long, J. T. Meek, and J. P. Reilly, J. Chem. Phys. 79, 3206 (1983).

${ }^{32}$ M. Meot-Ner (Mautner), P. Hamlet, E. P. Hunter, and F. Field, J. Am. Chem. Soc. 100, 5466 (1978).

${ }^{33}$ K. Hiraoka, S. Fujimaki, and K. Argua, J. Chem. Phys. 95, 8413 (1991).

${ }^{34}$ M. Meot-Ner (Mautner) and M. S. El-Shall, J. Am. Chem. Soc. 108, 4386 (1986).

${ }^{35}$ ACUCHEM, Version 1.4, Copyright: National Institute of Standards and Technology, Nov. 7, 1986.

${ }^{36}$ S. G. Lias, J. F. Liebman, and R. D. Levin, J. Phys. Chem. Ref. Data 13, 695 (1984).

${ }^{37}$ A. M. DE P. Nicholas, R. J. Boyd, and D. R. Arnold, Can. J. Chem. 60, 3011 (1982)

${ }^{38}$ A. A. Maryott and F. Buckley, Tables of Dielectric Constants and Electric Dipole Moments of Substances in the Gaseous State, National Bureau of Standards Circ. 537, June 25, 1953.

${ }^{39}$ R. D. Levin and S. G. Lias, Ionization Potential and Appearance Potential Measurements, 1971-1981, National Bureau of Standards, 1982. 